\title{
Study of 8x and 6x triticale with dominant Vrn genes
}

\author{
P.I. Stepochkin \\ Siberian Research Institute for Plant Industry and Breeding - Branch of the Institute of Cytology and Genetics, SB RAS, Krasnoobsk, Novosibirsk region, Russia
}

DOI 10.18699/ICG-PlantGen2019-68

(c) Autor, 2019

*e-mail: petstep@ngs.ru

\begin{abstract}
Secondary hexaploid (6x) triticale plants made by hybridization of a $6 x$ winter triticale variety with octaploid (8x) triticale plants bearing the dominant Vrn1 gene have different "shoots - earing" interphase period durations, which forms the following series: $6 \times V r n D 4 \geq 6 \times V r n B 1>6 x V r n D 1 \geq 6 x V r n A 1$. Plants of $8 x$ triticale compared with $6 x$ ones have denser spikes and a higher seed set. Plants of line $8 \times V r n D 4$ had the longest "shoots - earing" interphase period ( $74.3 \pm 1.7$ days) among all $8 x$ triticale studied in 2018 , while $8 x V r n D 1$ triticale plants had the shortest one ( $49.5 \pm 2.6$ days). Plants of $6 \mathrm{xVrnA} 1$ triticale had the shortest "shoots-earing" interphase period ( $47.4 \pm 0.9$ days) among all $6 x$ triticale studied. Plants of the triticale $8 \times V r n D 1$ and $6 \times V r n D 1$ inherited, from the wheat 'Triple Dirk E', the Ne1 and $\mathrm{Ne} 2$ genes that accounted for the manifestation of leaf hybrid necrosis and a low seed set. Secondary $6 x$ triticale with the dominant VrnA1 gene possesses the shortest "shoots earing" interphase period and a good seed set and is used in triticale breeding programs. Key words: octaploid; hexaploid; triticale; Vrn genes; interphase period.
\end{abstract}

\section{Introduction}

There are three levels of ploidy of a synthetic wheat-rye allopolyploid or triticale ( $\times$ Triticosecale sp. Wittmack). They are tetraploid (4x), hexaploid (6x) and octaploid (8x). Although a lot of triticale varieties are of $6 \mathrm{x}$ level of ploidy, some octaploid triticale varieties were made in China (Zhi-Jun Cheng, Minoru Murata, 2002). According to the lifestyle and the type of plant development, there are winter, spring and winter-spring or alternative triticales. The spring- type development and the duration of the "shoots-earing" interphase are determined by dominant $\mathrm{Vr} n$ genes located on wheat chromosomes $5 \mathrm{~A}$, 5B and 5D (Fu et al., 2005; Yoshida et al., 2010) and on rye chromosome 5R (Plaschke et al., 1993). In this report, some results of studying $8 \mathrm{x}$ and $6 \mathrm{x}$ triticales with dominant $\mathrm{Vrn}$ genes are given and discussed.

\section{Materials and methods}

Triticale (Trl) of two ploidy levels was created and studied in the Siberian Research Institute of Plant Growing and Breeding, a branch of the Institute of Cytology and Genetics, SB RAS. In the octaploid (8x) triticale nursery in 2018, we studied 4 forms of primary $8 \mathrm{x}$ wheat-rye amphidiploids (WRA): $8 \mathrm{x}$ VrnAl (genotype VrnAlVrnA1 vrnBlvrnB1 vrnDlvrnD1 vrnD4vrnD4), 8xVrnD1 (genotype vrnA1vrnA1 vrnB1vrnB1 VrnD1VrnD1 vrnD4vrnD4), 8xVrnB1 (genotype vrnA1vrnA1 VrnB1VrnB1 vrnD1vrnD1 vrnD4vrnD4) and $8 \mathrm{x} V r n D 4$ (genotype vrnAlvrnAl vrnBlvrnB1 vrnDlvrnD1 VrnD4VrnD4) created by the artificial doubling of chromosome number of wheat-rye hybrids from crosses between the winter rye variety 'Korotkostebelnaya 69' (genotype $v r n R 1$ ) and four soft wheat lines, 'Triple Dirk D', 'Triple Dirk B', 'Triple Dirk E' and 'Triple Dirk F' as donors of four different dominant genes, $V r n-V r n A 1, V r n B 1, V r n D 1$ and $V r n D 4$, correspondently (Stepochkin, 2009). In the nursery of hexaploid (6x) triticale, we studied $\mathrm{F}_{6}$ hybrids obtained from crosses, in 2014, between four primary octaploid triticale $(8 \mathrm{x} \operatorname{VrnA1}, 8 \mathrm{x} \operatorname{Vrn} D 1,8 \mathrm{x} \operatorname{Vrn} B 1$ and $8 \mathrm{x} V r n D 4)$ and the winter hexaploid triticale 'Sirs 57' (6x winter Trl) bearing recessive vrn genes. In this nursery, we also studied the 6x triticale forms $6 \mathrm{x} \operatorname{Vrn} A 1,6 \mathrm{x} \operatorname{Vrn} B 1,6 \mathrm{x} \operatorname{Vrn} D 1$ and $6 \mathrm{x} V r n D 4$ derived from the populations of $8 \mathrm{x}$ triticale with dominant $V r n$ genes. During the vegetation period from shooting to ripening, we carried out phenological observations. Qualitative and quantitative traits were studied.

\section{Results and discussion}

Spikes of $6 x$ triticale morphologically differ from those of $8 x$ triticale and are close to those in rye (Figure 1).

Their ears are denser than those of the original 8x WRA and their seed set is almost two times higher than that of $8 \mathrm{x}$ triticale (Table 1). For these traits, the hexaploid triticale plants of both groups do not differ significantly from each other except for 6x VrnD1. Plants of this WRA, as well as those of the $\mathrm{F}_{6}$ hybrid $(8 \mathrm{x} V r n D 1 \times 6 \mathrm{x}$ winter $\mathrm{Trl})$ and the octaploid WRA $8 \times \mathrm{VrnD} 1$ have two qualitative traits, leaf necrosis and hairy glumes, inherited from the initial wheat line 'Triple Dirk E', the maternal parental form and the donor of the dominant $V r n D 1$ gene for producing the $8 \mathrm{x} V r n D 1$ triticale (Stepochkin, 2009). Leaf necrosis, perhaps, led to the low seed set in the spikes of plants of the WRA made on the basis the wheat line 'Triple Dirk E'. It is known that a hybrid leaf necrosis caused by a complementary action of the $\mathrm{Ne}_{1}$ and $\mathrm{Ne}_{2}$ genes leads to grain production problems in wheats developed by interspecies crosses or crosses between a winter and a spring variety (Hermsen, 1963). The wheat line 'Triple Dirk E' is of hybrid origin (Goncharov, 2012).

Triticale plants bearing the dominant $V r n A 1$ or $V r n D 1$ gene have a shorter "shoots - earing" interphase period than those that bear the dominant $\operatorname{VrnB1}$ or $\operatorname{VrnD} 4$ gene. The plants that have the dominant $\mathrm{VrnD} 4$ gene show the longest duration of this period. Both the hexaploid triticale and the primary octaploid triticale plants bearing the dominant $V r n$ gene have "shoots - earing" interphase period duration that forms the following series: $\operatorname{Trl} V r n D 4 \geq \operatorname{Trl} V r n B 1>\operatorname{Trl} V r n D 1 \geq \operatorname{Trl}$ $\operatorname{VrnA1}$. Plants of line $8 \mathrm{x} V r n D 4$ had the longest "shoots - earing" period ( $74.3 \pm 1.7$ days) among all $8 \mathrm{x}$ triticale studied, while $8 \mathrm{x} V r n D 1$ triticale plants had the shortest one $(49.5 \pm 2.6$ 


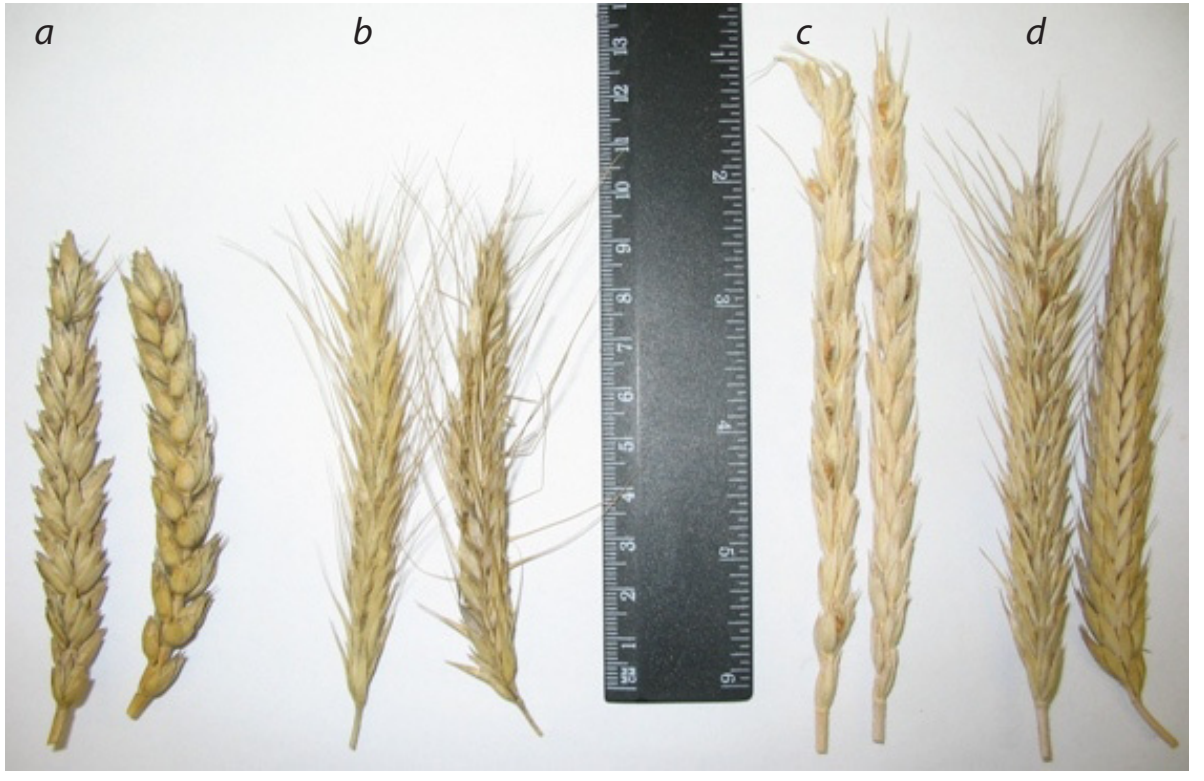

Figure 1. Spikes of common wheat 'Triple Dirk D' (a), winter rye 'Korotkostebelnaya' (b), $8 \mathrm{x}$ triticale $8 \mathrm{x} \operatorname{VrnA} 1$ (c) and $6 \mathrm{x}$ triticale 6xVrnA1.

Table 1

Duration of the "shoots - earing" period, spike density and spike grain number of 8x and 6x triticales with dominant Vrn genes

\begin{tabular}{|c|c|c|c|}
\hline Names of triticale & $\begin{array}{l}\text { Duration of the "shoots - earing" } \\
\text { period, days }\end{array}$ & $\begin{array}{l}\text { Spike density, number } \\
\text { of spikelets / length of spike }\end{array}$ & Spike grain number \\
\hline $8 x \operatorname{rnA} 1$ & $51.0 \pm 1.8$ & $1.89 \pm 0.02$ & $22.5 \pm 0.6$ \\
\hline 8xVrnD1 & $49.5 \pm 2.6$ & $1.74 \pm 0.03$ & $7.8^{*} \pm 1.3$ \\
\hline $8 x \operatorname{rnB} 1$ & $71.2 \pm 4.3$ & $1.87 \pm 0.03$ & $12.3 \pm 1.1$ \\
\hline $8 x \operatorname{VrnD} 4$ & $74.3^{*} \pm 1.7$ & $1.85 \pm 0.02$ & $11.0 \pm 0.7$ \\
\hline $8 x \operatorname{VrnA} 1 \times 6 x$ winter $\operatorname{Trl}$ & $45.1 \pm 2.5$ & $2.93 \pm 0.05$ & $38.9 \pm 3.0$ \\
\hline $8 \mathrm{xVrnD} 1 \times 6 \mathrm{x}$ winter $\mathrm{Trl}$ & $55.2 \pm 6.7$ & $2.98 \pm 0.06$ & $27.4^{*} \pm 2.7$ \\
\hline $8 \times \mathrm{VrnB} 1 \times 6 \times$ winter $\mathrm{Trl}$ & $56.4 \pm 2.1$ & $2.97 \pm 0.06$ & $42.9 \pm 1.7$ \\
\hline $8 x \operatorname{rnD} 4 \times 6 x$ winter $\mathrm{Trl}$ & $67.0 \pm 5.2$ & $2.85 \pm 0.13$ & $42.0 \pm 3.6$ \\
\hline $6 x \operatorname{VrnA} 1$ & $47.4 \pm 0.9$ & $3.00 \pm 0.06$ & $38.0 \pm 2.6$ \\
\hline $6 x \operatorname{VrnD} 1$ & $49.2 \pm 0.6$ & $3.17^{*} \pm 0.04$ & $28.0^{*} \pm 1.5$ \\
\hline $6 x \operatorname{VrnB1}$ & $58.9 \pm 0.4$ & $2.95 \pm 0.04$ & $35.0 \pm 1.6$ \\
\hline $6 x \operatorname{rnD} 4$ & $70.8^{*} \pm 0.7$ & $2.90 \pm 0.06$ & $42.8 \pm 2.7$ \\
\hline
\end{tabular}

* Significant difference at $p<0.05$.

days). Hexaploid triticales derived from octaploid WRA populations as a result of spontaneous depolyploidization and elimination of 14 chromosomes of the D genome (Stepochkin, 1978; Zhi-Jun Cheng, Minoru Murata, 2002; Li et al., 2015). They are of breeding interest. Plants of 6xVrnAl triticale had the shortest "shoots-earing" interphase period $(47.4 \pm 0.9$ days) among all $6 \mathrm{x}$ triticale studied. The $\mathrm{F}_{6}$ hybrid lines from cross of $8 \mathrm{x} V r n A 1 \times 6 \mathrm{x}$ winter triticale showed the shortest "shoots-earing" interphase period and a good seed set among all triticales studied, which also makes it promising for further breeding programs.

\section{Conclusions}

The results of the study of two-level ploidy triticales showed that the secondary hexaploid triticale plants made by hybridization of a $6 \mathrm{x}$ winter triticale variety with octaploid triticale plants bearing the dominant $\mathrm{Vrn} 1$ gene have different "shoots- earing" interphase period durations and form the following series: $6 \mathrm{x} V r n D 4 \geq 6 \mathrm{x} V r n B 1>6 \mathrm{x} V r n D 1 \geq 6 \mathrm{x} V r n A 1$. Plants of $8 \mathrm{x}$ triticale compared with $6 \mathrm{x}$ ones have denser spikes and a higher seed set. Plants of line $8 \mathrm{x} V r n D 4$ had the longest "shoots - earing" period ( $74.3 \pm 1.7$ days) among all $8 \mathrm{x}$ triticale studied in 2018, while $8 \times \operatorname{VrnDl}$ triticale plants had the shortest one $(49.5 \pm 2.6$ days). Plants of $6 x \operatorname{VrnA} 1$ triticale derived from the population of $8 \mathrm{x}$ triticale as a result of spontaneous depolyploidization and elimination of $\mathrm{D}$-genome chromosomes had the shortest "shoots - earing" interphase period (47.4 \pm 0.9 days) among all $6 \mathrm{x}$ triticale studied. $8 \mathrm{x} \operatorname{VrnD} 1$ and $6 \mathrm{x} \operatorname{VrnD} 1$ triticale plants inherited the $\mathrm{Ne}_{1}$ and $\mathrm{Ne}_{2}$ genes from the wheat 'Triple Dirk E', which accounted for the manifestation of leaf hybrid necrosis and a low seed set. As the secondary 6x triticale with the dominant $\operatorname{VrnAl}$ gene combines the shortest "shoots-earing" interphase period and a good seed set, it is used in triticale breeding programs. 


\section{References}

Fu D., Szücs P., Yan L., Helguera M., Skinner J.S., Zitzewitz J., Hayes P.M., Dubcovsky J. Large deletions within the first intron in VRN-1 are associated with spring growth habit in barley and wheat. Mol. Gen. Genomics. 2005;273:54-65.

Goncharov N.P. Comparative genetics of wheat and their related species. Novosibirsk: Academic publishing house "Geo", 2012 (in Russian).

Hermsen J.G.Th. Hybrid necrosis as a problem for the wheat breeder. Euphytica. 1963;12(1):1-16.

Li H., Guo X., Wang C., Ji W. Spontaneous and divergent hexaploid triticales derived from common wheat $\times$ rye by complete elimination of D-genome chromosomes. PLOS One. 2015:1-12. DOI:10.1371/ journal.pone.0120421.

Plaschke J., Börner A., Xie D.X., Koebner R.M.D., Schlegel R., Gale M.D. RFLP mapping of genes affecting plant height and growth habit in rye. Theor. Appl. Genet. 1993;85:1049-1054.
Stepochkin P.I. Development and study of a set of triticale forms as to the VRN genes. Sib. J Agricultural Sci. 2009;11:26-32 (in Russian).

Yoshida T., Nishida H., Zhu J., Nitcher R., Distelfeld A., Akashi Y., Kato K., Dubcovsky J. Vrn-D4 is a vernalization gene located on the centromeric region of chromosome 5D in hexaploid wheat. Theor. Appl. Genet. 2010;120:543-552.

Zhi-Jun Chen, Minoru Murata. Loss chromosomes 2R and 5RS in octoploid triticale selected for agronomic traits. Genes. Genet. Syst. 2002;7:23-29.

Acknowledgements. This work was supported by ICG budget project No. 0324-2019-0039 in part of field trial and experimental measurements.

Conflict of interest. The author declares no conflict of interest. 